\title{
The Spirit of Contradiction in the Buddhist Doctrine of Not-Self
}

\author{
Hugh Nicholson \\ Loyola University Chicago, hnicholson@luc.edu
}

Follow this and additional works at: https://ecommons.luc.edu/theology_facpubs

Part of the Religious Thought, Theology and Philosophy of Religion Commons

\section{Recommended Citation}

Nicholson, Hugh. "The Spirit of Contradiction in the Buddhist Doctrine of Not-Self." The Journal of Religion, 92, no. 1 (2012): 31-57.

This Article is brought to you for free and open access by the Faculty Publications and Other Works by Department at Loyola eCommons. It has been accepted for inclusion in Theology: Faculty Publications and Other Works by an authorized administrator of Loyola eCommons. For more information, please contact ecommons@luc.edu.

\section{(c) $(\mathrm{i})(\mathrm{EY}$}

This work is licensed under a Creative Commons Attribution-Noncommercial-No Derivative Works 3.0 License. (c) 2012 The University of Chicago Press. 


\title{
The Spirit of Contradiction in the Buddhist Doctrine of Not-Self*
}

\author{
Hugh Nicholson / Loyola University Chicago
}

In his comprehensive and authoritative study of the doctrine of "notself" (Pāli anattā; Sanskrit anātman) in Theravāda Buddhism, Selfless Persons (1982), Steven Collins identifies two distinct functions of this doctrine. He correlates these functions, moreover, to a sociological distinction between the religious specialist and the ordinary Buddhist. Thus, in the context of the practice of the analytical "insight" meditation practiced by members of the former group, the anatta doctrine refers to "the classification of any experience or concept into a known, nonvalued, impersonal category." ${ }^{1}$ Such classification or redescription of experience serves as an effective technique for cultivating an attitude of disinterest toward the object thus classified, thus negating the desire that, according to the Buddha's Second Noble Truth, is the root cause of suffering. ${ }^{2}$ For the vast majority of Buddhists, however, who do not practice such meditation, the doctrine's main function was to provide "an intransigent symbolic opposition to Brahmanical thought." ${ }^{3}$ Because Collins associates this latter, oppositional dimension of the anatta doctrine with those Buddhists lacking in specialized knowledge of the doctrine or a commitment to the corresponding regimens of meditative practice, one might be tempted to infer that this political-ideological function of anatta appears only in default of the former, as a kind of

\footnotetext{
* I presented several of the ideas contained in this article in a talk I gave at the Center for the Study of World Religions at Harvard Divinity School on February 16, 2011; I have benefited greatly from the feedback I received in the discussion that followed. I am grateful to the three anonymous reviewers of this article for their constructive criticism and suggestions.

${ }^{1}$ Steven Collins, Selfless Persons (Cambridge: Cambridge University Press, 1982), 173. Hereafter, Sanskrit will be abbreviated as "Skt." and Pāli as "Pā."

${ }^{2}$ Ibid., 173, 113.

${ }^{3}$ Ibid., 77, see also 12. Richard Gombrich (Buddhist Precept and Practice [Delhi: Motilal Banarsidass, 1991], 86) observes that most of those Buddhists he encountered in Śri Lanka assented to the doctrine without being able to articulate it.
}

(C) 2012 by The University of Chicago. All rights reserved.

0022-4189/2012/9201-0002\$10.00 
degenerative form thereof. ${ }^{4}$ He notes, no doubt correctly, that the specialized understanding and application of the anatta doctrine have played no significant role in the religious lives of the vast majority of Buddhists. ${ }^{5}$ What remains unclear, however, is the extent to which the inverse relation holds true, that is, what role, if any, the oppositional aspect of the doctrine has played in the religious formation of those Buddhists who undertake the spiritual exercises informed by the specialized understanding of the anatta doctrine.

In this article I would like to reflect on this relation between what might be called the political-oppositional and the spiritual-transformative dimensions of the anatta doctrine. In explicating each of these dimensions of the doctrine I will be drawing from the excellent work that has been done by scholars such as Collins, Richard Gombrich, and Johannes Bronkhorst, among others. With respect to the politicaloppositional dimension of anattāa, I will be foregrounding a theme that is largely secondary in those works. What I hope to add substantively to the discussion, however, is the suggestion that the oppositional aspect of the anatta doctrine is linked, albeit indirectly, to the meditative program of cultivating attachment.

In this task of relating the political and the spiritual aspects of anatt $\bar{a}$ I find it helpful to understand this central Buddhist teaching as a theological doctrine rather than as a philosophical inference or an immediate datum of religious experience. ${ }^{6}$ For, as I shall argue presently, the category of theological doctrine, understood as communally authoritative discourse that sustains the identity of a religious community, foregrounds both the oppositional aspect of authoritative religious discourse

\footnotetext{
${ }^{4}$ Although Collins speaks of these two uses of anattā doctrine as alternatives-for the ordinary Buddhist, the anattā doctrine functions symbolically and ideologically, whereas for the Buddhist specialist it is taken literally and personally (Selfless Persons, 12) - I suspect he would be uncomfortable with this inference.

${ }^{5}$ Collins, Selfless Persons, 94, 68; cf. Melford E. Spiro, Buddhism and Society (Berkeley: University of California Press, 1982), 84-89.

${ }^{6}$ I should distinguish the approach taken here from that of the proponents of "Buddhist theology" (a movement with which, I might add, I happen to be quite sympathetic). To propose theological doctrine as a useful heuristic category of analysis is obviously not the same thing as arguing for the appropriateness and legitimacy of engaging religious-normative concerns in the academic study of Buddhism. For the latter argument, see, e.g., John Makransky, "Editor's Introduction," pt. 2, "Contemporary Academic Buddhist Theology: Its Emergence and Rationale," in Buddhist Theology: Critical Reflections by Contemporary Buddhist Scholars, ed. Roger L. Jackson and John J. Makransky (New York: Routledge, 2000), 14-19; Rita M. Gross, "Buddhist Theology?" in Jackson and Makransky, Buddhist Theology, 53-60; Malcolm David Eckel, "The Ghost at the Table: On the Study of Buddhism and the Study of Religion," Journal of the American Academy of Religion 62, no. 4 (Winter, 1994): 1085-1110. Here I adopt a more standard academic approach that aims at more or less neutral description.
} 
and the role of such discourse in religious formation. ${ }^{7}$ It is thus able to reveal a dimension of the anatta doctrine that is often hidden when one follows the more usual procedure of regarding this doctrine as a philosophical proposition and/or as a phenomenological description of religious experience. ${ }^{8}$

\section{ANATTĀ AS THEOLOGICAL DOGTRINE}

Most modern interpreters of classical Indian thought who have sought to engage Indian intellectual traditions beyond the historical and philological analysis of texts have viewed these texts through the lens of the concept of philosophy. Their use of the category of philosophy, by focusing attention on the arguments that Buddhists, Brahmins, and Jains have used to explain and defend the teachings of their respective traditions, has successfully overcome a pervasive failure, stemming from age-old orientalist tendencies to view Indian thought as "mystical," intuitive, and otherworldly and to acknowledge the intellectual rigor of classical Indian thought in general and Buddhist thought in particular. ${ }^{9}$ More recently, the category of philosophy has been broadened to encompass the transformative-spiritual dimension of Buddhist, Hindu, and

\footnotetext{
${ }^{7}$ Here my use of the term "theology" obviously extends beyond its etymological sense, in which case it would be valid only for theistic traditions. Rather, I follow José Cabezón ("Buddhist Theology in the Academy," in Jackson and Makransky, Buddhist Theology, 25) in understanding "theology" more broadly as "a form of normative discourse, self-avowedly rooted in tradition, with certain formal properties."

${ }^{8}$ Having announced a preference for one comparative category with respect to a specific area of interest, let me quickly add, to avoid any possible misunderstanding, that I do not claim that the category of theological doctrine is superior in any absolute sense to any of the alternatives for understanding the doctrine of not-self. If the use of comparative categories in understanding other cultures is unavoidable (see, e.g., Charles Taylor, "Comparison, History, Truth," in Myth and Philosophy, ed. Frank Reynolds and David Tracy [Albany: SUNY Press, 1990], 41), as I believe it is, there nevertheless remains a degree of flexibility in the specific choice of categories the scholar can use. The use of a given comparative category is justified to the extent that it sheds light on the phenomenon studied; its value is determined by its heuristic power with respect to a specific question or concern. Comparative categories function like metaphors in that different categories foreground different aspects of reality. On the latter point, see Fitz John Porter Poole, "Metaphors and Maps: Towards Comparison in the Anthropology of Religion," Journal of the American Academy of Religion 54, no. 3 (Autumn 1986): $414-15,420$. The choice of category therefore is largely dictated by the scholar's theoretical interests. See Jonathan Z. Smith, Drudgery Divine (Chicago: University of Chicago Press, 1990), 53.

${ }^{9}$ An exemplary recent example of this approach is Parimal G. Patil, Against a Hindu God (New York: Columbia University Press, 2009), esp. 9-10, 16; other notable studies of Buddhism from a philosophical point of view are Dan Arnold, Buddhists, Brahmins, and Belief (New York: Columbia University Press, 2005), 7-9, 205; Matthew T. Kapstein, Reason's Traces (Boston: Wisdom Publications, 2001); Claus Oetke, "Ich" und das Ich (Stuttgart: Steiner, 1988).
} 
Jain teachings. Inspired by the seminal work of Pierre Hadot in Hellenistic philosophy, scholars like Matthew Kapstein, Dan Arnold, and Francis Clooney have given closer consideration to the broader context of philosophical claims and arguments in various techniques of selfcultivation. ${ }^{10}$ Even with this shift from what Kapstein calls a "problems and arguments approach" in the study of philosophy to the broader conception of philosophy as spiritual exercise, however, the category of philosophy is ill equipped to handle that other element in the problematic that concerns us, namely, the polemical and ideological dimension of the anattā doctrine. Philosophical approaches to the study of the history of Buddhist thought, while duly acknowledging the sectarian and polemical character of many classical Buddhist texts, tend to downplay the significance of the polemical aspects of those texts in their effort to explicate their philosophical meaning. A particularly revealing passage in this regard can be found in the introduction of Kapstein's Reason's Traces. Referring to those sections of Sāntarakșita's Tattvasaingraha that are devoted to a refutation of Sāmkhya doctrine, Kapstein asks, "Now, how does the study of this and its refutation properly belong to the program of self-culture through spiritual exercise that we have been discussing? For on the surface, at least, it appears that Santarakșita's purpose is primarily to dismiss the teachings of Buddhism's opponents and to defend the faith; philosophical argument, so it seems, is deployed here primarily in the service of doctrinal apologetics." 11 While recognizing the legitimacy of this line of interpretation, Kapstein feels compelled to offer "an alternative reading," namely, that the rival doctrines Śāntarakșita refutes represent deficient modes of self-understanding such that doctrinal apologetics ultimately functions as a kind of therapeutic exercise. Now, while I must confess to finding this alternative interpretation quite compelling, I would question the assumption that appears to motivate it, namely, that doctrinal apologetics has little to do with "the program of self culture through spiritual exercise." I suspect that Kapstein's approach to the polemical aspects of Sāntarakșita's text betrays a normative conception of philosophy that regards the elements of partisanship found in the history of philosophy as for-

\footnotetext{
${ }^{10}$ Kapstein, Reason's Traces, 7-8; cf. Arnold, Buddhists, Brahmins, and Belief, 212-13; Francis X. Clooney, Beyond Compare (Washington, DC: Georgetown University Press, 2008), 79-82. Paul Griffiths's conception of scholastic reading also emphasizes the transformative dimension of doctrine and argument. See his "Scholasticism: The Possible Recovery of an Intellectual Practice,” in Scholasticism, ed. José Ignacio Cabezón (Albany: SUNY Press, 1998), 214, 217.

${ }^{11}$ Kapstein, Reason's Traces, 15.
} 
eign to its spirit or essence. ${ }^{12}$ The following statement of Gilbert Ryle, which would pertain to much of classical Indian philosophy, is a paradigmatic expression of this attitude: ${ }^{13}$ "The alleged party issues are never the important philosophic questions, and to be affiliated to a recognizable party is to be the slave of nonphilosophic prejudice in favour of a (usually nonphilosophic) article of belief. To be a 'so-and-so-ist' is to be philosophically frail. And while I am ready to confess or to be accused of such a frailty, I ought no more to boast of it than to boast of astigmatism or mal de mer." ${ }^{14}$ Put differently, philosophy, certainly in its modern, "antischolastic" forms, is constitutively opposed to what the sociologist Lewis Coser, following Georg Simmel, terms "non-realistic conflict," that is, conflict that is not reducible to the specific issue of disagreement but rather is motivated by a formal impulse to differentiate one group from another. ${ }^{15}$ A philosopher like Ryle does not object to polemic in philosophy so long as the polemic derives from material disagreement, in other words, that it is "realistic," in Coser's sense. What he objects to, rather, is ideological commitment as the basis and motive for philosophical disagreement. ${ }^{16}$ As I shall argue below, this a priori "spirit of contradiction" (Simmel) is an undeniable feature of the historical development of the doctrine of not-self.

Thus, while scholars of Buddhism have recently expanded the concept of "Buddhist philosophy" to include Hadot's notion of "spiritual exercise," a normative self-understanding of philosophy interferes with an acknowledgment of the role of social opposition in the processes of

\footnotetext{
${ }^{12}$ If the category of philosophy is understood broadly to include scholasticism, then it can recognize the apologetic and ideological elements of philosophical argumentation. See Cabezón, "Introduction," in Scholasticism, 4-5. But it is precisely the scholastic element of traditional philosophy that tends to be regarded unfavorably by modern philosophy. See Cabezón, "Introduction," 2-3; Griffiths, "Scholasticism," 201.

${ }^{13}$ Incidentally, I suspect that this partisan or scholastic feature of classical Indian thought, more than a still pervasive failure to acknowledge the intellectual rigor of Indian philosophy or the more sophisticated hermeneutical claim that the Wirkungsgeschichte of classical Indian thought does not extend to the intellectual traditions of the West (see, e.g., Patil, Against a Hindu God, 6; Paul Ricoeur, The Symbolism of Evil, trans. Emerson Buchanan [Boston: Beacon, 1967], 22-23) is responsible for the fact that relatively few Western philosophers have been persuaded to give Indian philosophy the serious consideration it deserves.

${ }^{14}$ Gilbert Ryle, "Taking Sides in Philosophy," in Collected Papers, vol. 2 (New York: Barnes \& Noble, 1971), 153-54.

${ }^{15}$ Lewis Coser, The Functions of Social Conflict (Glencoe, IL: Free Press, 1956), 48-55; cf. Georg Simmel, Conflict and the Web of Group-Affiliations, trans. Kurt H. Wolff and Reinhard Bendix (New York: Free Press, 1955), 28-30.

${ }^{16}$ Ryle, "Taking Sides," 156 . The distinction between realistic and nonrealistic conflict in the context of intellectual discussion roughly corresponds to the distinction early Nyāya made between $v \bar{a} d a$, a discourse motivated by a quest for truth, and jalpa, a discussion motivated by a quest for victory.
} 
religious formation. By contrast, the category of specifically theological doctrine, here defined, adapting a formulation of George Lindbeck, as "communally authoritative teaching considered essential to the identity of the community in question," foregrounds both these aspects of Buddhist teaching. ${ }^{17}$ To that extent, it is better suited to explore the relation between the spiritual-transformative and the oppositional-ideological dimensions of the anatta doctrine.

That theological doctrine plays a role in shaping the way human beings experience and understand the world has been widely acknowledged in the scholarly literature on the subject at least since Lindbeck's influential book The Nature of Doctrine (1984). Clearly distinguishing his position from both the traditionalist, "cognitive-propositional" understanding of doctrines as informative truth claims about objective realities and the liberal, "experiential-expressive" theory of doctrines as expressions or symbolizations of inner religious experiences, Lindbeck argues that doctrines function primarily as authoritative rules of communal discourse and action. ${ }^{18}$ Drawing on the work of Clifford Geertz, Lindbeck emphasizes the role of doctrine, in concert with other outward features of religious life such as ritual and sacrament, in shaping individual and communal experience.

Theorists of doctrine, particularly those who approach the subject from a standpoint of theological commitment, have been somewhat more reluctant to recognize the centrality of the second aspect of theological doctrine that I wish to highlight, namely, its political role in mobilizing religious communities against their proximate rivals. ${ }^{19}$ And yet, I would argue that this political-oppositional function of doctrine follows logically from the regulative function highlighted by Lindbeck. Inasmuch as a religious community with a clear sense of identity is not simply a given but is rather something actively constructed and maintained through ongoing acts of differentiation and mobilization, the regulative function of doctrine presupposes the "political" mobilization

\footnotetext{
${ }^{17}$ Lindbeck's actual formulation is the following: "Church doctrines are communally authoritative teachings regarding beliefs and practices that are considered essential to the identity or welfare of the group in question" (George A. Lindbeck, The Nature of Doctrine [Philadelphia: Westminster, 1984], 74).

${ }^{18}$ Ibid., 79-84, 104-8.

${ }^{19}$ For example, Paul Griffiths, while recognizing the use of doctrine to demarcate religious communities as a legitimate use thereof, nevertheless classifies this as a "nondoctrinal" use of doctrine (On Being Buddha [Albany: SUNY Press, 1994], 21). The boundary marking function of doctrine is extrinsic to the two primary, "properly doctrinal" uses he recognizes, namely, to describe the nature of things and to recommend forms of action and attitude to those standing in the sphere of a given doctrine's authority (21-23). Griffiths's classification of the boundary marking function of doctrine as extrinsic to its properly doctrinal use reflects his unapologetically formalist approach to doctrine $(2-3,29)$.
} 
of community. ${ }^{20}$ The community whose speech and behavior are to be regulated must first be set off from others through various discursive-of which one is doctrine-and nondiscursive means. ${ }^{21}$ Thus understood, the category of theological doctrine unites the two dimensions of the anattā doctrine mentioned above: doctrines play a part in shaping religious experience, and they mobilize communal identity through differentiation.

\section{THE EMERGENCE OF ANATTĀ AS A MARK OF BUDDHIST IDENTITY}

It is clear that the not-self doctrine was a response to the concept of the àtman in contemporary Brahmanical thought. Eventually the anattā doctrine became a touchstone for Buddhist identity. ${ }^{22}$ Certainly by the time we get to Vasubandhu (early fifth century CE), the denial of a self or àtman-understood as a reality transcending the physical and psychic constituents (Pā. khandha, Skt. skandha) of the human organism-had become, at least for certain Buddhist schools, a sine qua non for liberation. ${ }^{23}$ It should be noted that the àtman that Buddhism originally rejected does not coincide with the absolute, abstract, and impersonal conception of the àtman in Advaita (Nondualist) Vedānta that is perhaps

\footnotetext{
${ }^{20}$ See the critique of this aspect of Lindbeck's postliberal theology in Kathryn Tanner, Theories of Culture (Minneapolis: Fortress, 1997), 104-19.

${ }^{21}$ Lindbeck himself highlights two features of doctrine that point directly to this underlying political-ideological dimension of doctrine. First, he observes that "doctrines must be understood in terms of what they oppose" (Nature of Doctrine, 75). It is relatively clear, for example, that although the Nicene doctrine of the Son as homoousios with the Father is notoriously ambiguous as an affirmation, it is easy to specify what it denied, namely, a subordination of the Word of God to God. Second, "the official doctrines of a community may poorly reflect its most important and abiding orientations or beliefs" (75). It is this second feature of doctrine, more than any other, that manifests an a priori impulse to distinguish one's community from others. The infamous iota that separated the Nicene homoousion from the antiNicene homoiousion in the later fourth-century Trinitarian controversies is a paradigmatic example of this. See Simmel, Conflict and the Web, 30; cf. Lindbeck, Nature of Doctrine, 76.

${ }^{22}$ Here I use the term "identity" to refer simply and rather blandly to the consciousness of Buddhism as a distinctive body of teaching and tradition. I certainly do not intend the term to imply a reference to a bounded and homogeneous social group as it does in modern nationalist ideologies. Pace Richard Handler ("Is 'Identity' a Useful Cross-Cultural Concept?" in Commemorations, ed. John R. Gillis [Princeton, NJ: Princeton University Press, 1994], 2740), I believe that the use of the term is compatible with a recognition that the symbolic boundaries that demarcate social groups are continually constructed and reconstructed in relation to their surroundings.

${ }^{23}$ Or, more accurately, a belief in such a self renders liberation impossible inasmuch as it serves as the fundamental instance of attachment. See Swāmī Dwārikādās Shāstrī, ed., Abhidharmakośa Ē Bhāsyya of Ācharya Vasubandhu with Sphuțārthā Commentary of Ācharya Yaśomitra, pt. 4 (Varanasi: Bauddha Bharati, 1973), 1189, lines 1-4: "kiṃ khalvato "nyatra mokṣo nāsti? nāsti. kiṃ kāraṇam? vitathātmadṛșținivișțatvāt" (translated as "Now, then, is no liberation [from the round of samsāra] to be found outside of this [teaching of the Buddha]? No, it is not. Why so? Owing to preoccupation with false views of self" in Kapstein, Reason's Traces, 350).
} 


\section{The Journal of Religion}

more familiar to students of Indian religion..$^{24}$ Unlike this Advaitic ātman, which, according to André Bareau, postdates the advent of Buddhism by at least five hundred years, ${ }^{25}$ the a tman familiar to the early Buddhist texts is an individualized, personal principle. We could perhaps say that this conception of the atman, which is found in the earliest Upanișads, is more proto-Sāṃkya than proto-Vedānta. ${ }^{26}$

The emergence of the anatta doctrine in the early, formative period of Buddhism can be understood in the context of the movement's oppositional stance toward the Brahmanical order more generally. ${ }^{27}$ Examples of such a stance, conveyed through striking and at times humorous images, can be found throughout the Pāli canon. ${ }^{28}$ For example,

${ }^{24}$ André Bareau, "La notion de personne dans le bouddhisme indien," in Problèmes de la personne, ed. Ignace Meyerson (Paris: Mouton, 1973), 96; David Seyfort Ruegg, Buddha-Nature, Mind, and the Problem of Gradualism in a Comparative Perspective (London: University of London, 1989), 20.

${ }^{25}$ Bareau, "La notion de personne," 96. Buddhist thinkers do not mention a specifically Vedāntic conception of the ätman only until rather late. The earliest mention of Vedānta seems to be Bhavaviveka; the earliest mention of Śankara's Advaita Vedānta in particular is Kamalaśîla. See Ruegg, Buddha-Nature, 21, no. 6; see also Kapstein, Reason's Traces, 113.

${ }^{26}$ Significantly, there is no mention of the neuter, absolute brahman in the Păli suttas. See E. J. Thomas, The History of Buddhist Thought, 2nd ed. (New York: Barnes \& Noble, 1951), 87, 96. According to Hermann Oldenberg (Die Lehre der Upanishaden und die Anfang des Buddhismus [Göttingen: Vandenhoeck \& Ruprecht, 1915], 295), the mention of an eternal self standing over against an eternal world like an immovable mountain peak ("yathā sassato attā ca loko ca vañjho kūtațtho esikațthāyițthito") in the Brahmajāla Sutta contains an unmistakable reference to the Sāmkhya doctrine of a duality between eternal spirit and nature (purușa and prakrti, respectively). And yet this same author qualifies the Sämkhya influence on early Buddhism by denying an "immediate dependence" (unmittelbare Abhängigkeit) of the latter on the former (294). We must not uncritically read later Vedāntic conceptions into the early Upanișads. As Hajime Nakamura (A History of Early Vedānta Philosophy, pt. 1, trans. Trevor Leggett, Segakul Mayeda, and Taitetz Unno [Delhi: Motilal Banarsidass, 1983], 429, cf. 105) observes, the Upanișads do not unambiguously teach atman/brahman as the only absolute; this interpretation of atman/brahman as the chief purport of the Upanișadic corpus is the achievement of the later Vedāntic school, starting with Bādarāyaṇa's Brahma-Sūtra (fifth century CE).

${ }^{27}$ When I speak here of the formative period of Buddhism or, alternatively, "early Buddhism," I refer to the period between the time of the Buddha (late sixth or fifth century BCE, depending on chronology) and the reign of the Mauryan king Aśoka (270-232 BCE; see Steven Collins, Nirvana and Other Buddhist Felicities [Cambridge: Cambridge University Press, 1998], 53-54). This period corresponds to what Frank E. Reynolds and Charles Hallisey ("Buddhism," in The Encyclopedia of Religions, ed. Mircea Eliade [New York: Macmillan, 1987], 337-38) term "sectarian Buddhism," where the adjective refers not to the proliferation of Buddhist sects (which appears later even if it had roots in the earliest period) but rather to "a certain distance, both self-perceived and real, from other religious communities, as well as from the society, civilization, and culture with which it coexisted" (337). With Aśoka's patronage of Buddhism in the third century BCE, Buddhism's sectarian phase gave way to a period in which Buddhism became what Reynolds and Hallisey term a "civilizational religion."

${ }^{28}$ The Pāli Canon, the Sutta and Vinaya Pițakas in particular, remains one of the earliest and certainly the most extensive and accessible sources for Buddhism's formative period. I am keenly aware that, as Jason Neelis (Early Buddhist Transmission and Trade Networks [Leiden: 
the Brahmajāla Sutta depicts a vain and somewhat ridiculous Brahma falsely imputing causal efficacy to his earlier wish for companionship when other transmigrating beings, their merit exhausted and falling from the world of radiance (äbhassarakaya), join him in this world ${ }^{29}$ In a similar vein, the Tevijja Sutta, in a famous image, compares the Vedic tradition with its claims of transcendent authority to a string of blind men, each following the one immediately before and all ultimately following a leader who is equally blind.$^{30}$ In seeking to invert the norms of a hegemonic Brahmanical order, however, early Buddhism generally employed a more oblique strategy. ${ }^{31}$ More often than not, Buddhism chose to redefine, rather than reject outright, key Brahmanical terms and concepts, such as brāhmana, dharma, ärya (noble; a member of one of the "twice-born" varnas), and karma. ${ }^{32}$ Thus the Buddha teaches that the true brähmana is not defined by his birth or his mastery of Vedic lore but rather by his moral virtue $($ silla $) .^{33}$ The Pāli term sutta, probably deriving from Sanskrit sūkta, the sacred hymns of the Veda (rather than

Brill, 2011], 42) puts it, "Pāli texts do not necessarily represent the oldest or relatively 'pure' versions of the Buddha's teachings," as confirmed by the relatively recent discovery of Gāndhārī manuscripts that predate the earliest extant Pāli manuscripts (42-44; Gregory Schopen, "Two Problems in the History of Indian Buddhsim" in Bones, Stones, and Buddhist Monks [Honolulu: University of Hawaii Press, 1997], 25; Richard Gombrich, What the Buddha Thought [London: Equinox, 2009], 98). According to the Pāli tradition itself, the Canon-or perhaps a rudimentary version thereof (Schopen, "Two Problems," 23-24) - was first written down at the end of the first century BCE, and while there is no reason to doubt that, as Collins (Nirvana and Other Buddhist Felicities, 54) notes, "many of the texts later redacted in writing do afford us reliable knowledge of pre-Aśokan texts," our knowledge of this period is unavoidably conjectural and sketchy.

${ }^{29}$ T. W. Rhys Davids and J. Estlin Carpenter, eds. The Digha Nikäya, vol. 1. (London: Pali Text Society, 1890), 17-18; F. Max Müller, ed. Sacred Books of the Buddhists, vol. 2. (London: Pali Text Society, 1973), 30-32. This passage probably alludes to the creation myth in Bṛhadāraṇyaka Upanișad 1.4.

${ }^{30}$ Müller, Sacred Books of the Buddhists, 305.

${ }^{31}$ In characterizing Brahmanical thought as hegemonic with respect to the larger culture of ancient India, I do not want to suggest that there was broad agreement among brahmins on the usage of the relevant terms and concepts. Even in the Vedic-Upanișadic era, that is, before the development of the classical schools of Brahmanical thought (Sāmkhya, Vaiśeșika, Mīmāmsāa etc.), there was rivalry among the various Vedic schools of recitation (śa $\bar{k} k h \bar{a})$. Thus the Upanișads, which represent a variety of saakhā affiliations, contain significant differences in the interpretation of key terms such as ätman, brahman, and karma. The issue of śäkhā affiliation and rivalry is a central theme in Signe Cohen's Text and Authority in the Older Upanisads (Leiden: Brill, 2008), esp. 1, 6, 10-13.

${ }^{32}$ On the Buddhist response to the Brahmanical order as an example of "normative inversion," see Sheldon Pollock, The Language of the Gods in the World of Men (Berkeley: University of California Press, 2006), 51-53. The term "normative inversion" comes from Jan Assmann, Moses the Egyptian (Cambridge, MA: Harvard University Press, 1997).

${ }^{33}$ See, e.g., the Soṇadanda Sutta (Müller, Sacred Books of the Buddhists, 152-57); cf. K. R. Norman, "Theravāda Buddhism and Brahmanical Hinduism: Brahmanical Terms in a Buddhist Guise," in The Buddhist Forum, vol. 2, ed. Tadeusz Skorupski (New Delhi: Heritage, 1992), 196. 
sütra), now refers to the Buddha's discourses-precisely the same discourses that, ironically, disparage Vedic learning. ${ }^{34}$ And most significantly perhaps, karma no longer refers primarily to sacrificial action but rather to the intention of action in general. ${ }^{35}$ In these examples, with the possible exception of the last, one might say, using the terminology of the philosopher C. L. Stevenson, that the emotive, laudatory meaning of the Brahmanical term is held constant, while its descriptive meaning is significantly altered-sometimes radically-in accordance with the often diametrically opposed interests and values of Buddhism. ${ }^{36}$ Frequently the term subject to radical redefinition acquires a profoundly ironic sense: the example of sutta/sukta mentioned above would be one; the use of the term originally referring to Vedic sacrifice, dharma (Pā. dhamma), to refer to the Buddha's teaching-one of whose salient features was a rejection of Vedic sacrifice-would be another. ${ }^{37}$ Such an oblique response is typical of movements forced to assert themselves in the idiom of a culturally dominant adversary. ${ }^{38}$ In other words, to adopt Michel de Certeau's felicitous military metaphor, it is an example of the "tactics" employed by a strategically disadvantaged party that "must play on and with a terrain imposed on it and organized by the law of a foreign power." ${ }^{39}$ By being tactically redefined in this way, certain key Brahmanical terms are transformed into metaphors. Thus brähmana becomes a metaphor for the virtuous person; ariya/ärya a metaphor for

\footnotetext{
${ }^{34}$ Pollock, Language of the Gods, 52.

${ }^{35}$ Richard Gombrich, How Buddhism Began (Atlantic Highlands, NJ: Athlone, 1996), 51-54, and Theravāda Buddhism: A Social History from Ancient Benares to Modern Colombo (New York: Routledge, 1988), 66-69. Gombrich (How Buddhism Began, 51) regards the Buddhist "ethicization" of karma as nothing less than "a turning point in the history of civilization."

${ }^{36}$ C. L. Stevenson, Ethics and Language (New Haven, CT: Yale University Press, 1944), 72; cf. Maurice Cranston, Freedom (London: Longman, Green, \& Co., 1953), 14-15. This strategy is not universal, of course. Sometimes an inversion of the emotive valence accompanies the redefinition of a term. For example, the Buddha's reinterpretation of the three Vedic fires as those of rāga, dosa, and moha, entails an obvious reversal of the term's emotive valence. See Norman, "Theravāda Buddhism and Brahmanical Hinduism," 194.

${ }^{37}$ Pollock, Language of the Gods, 51.

${ }^{38}$ See Collins, Selfless Persons, 32, on the "culturally hegemonous" position of Brahmanical thought vis-à-vis early Buddhism. See also Greg Baily and Ian Mabbett, The Sociology of Early Buddhism (Cambridge: Cambridge University Press, 2003), 121: "A heterodox or minority tradition needs to relate itself to the orthodox or mainstream practice; almost necessarily, Buddhism mapped itself upon a structure supplied by the brahmins, defining itself by reference to what it was not; a series of systematic oppositions identified its relationship to the pre-existing orthodoxy."

${ }^{39}$ Michel de Certeau, The Practice of Everyday Life, trans. Steven Rendall (Berkeley: University of California Press, 1984), 37. As "an art of the weak" tactics involve guile and deception. See Cranston, Freedom, 15, on the deceptive quality of Stevenson's concept of "persuasive" definition.
} 
the Buddhist adherent; action (kamma/karma) becomes a metaphor for the intention behind an action. ${ }^{40}$

This idea of forging a distinctive sense of identity by ironically troping the terminology of a hegemonic adversary sheds light on the controversial question of early Buddhism's stance with respect to the atman. The locus classicus of the not-self doctrine in the Pāli canon is the Anattalakkhana Sutta ("Discourse on the [fact of things having the] Characteristic of Not-self"), ${ }^{41}$ traditionally the Buddha's second sermon. In a formulaic dialogue found in several places in the Canon, the Bud$\mathrm{dha}^{42}$ pursues the following line of questioning with five disciples regarding the five constituents (khandha), starting with physical form or body $($ rūpa $)$ :

What do you think, O monks, is the body permanent or impermanent?

Impermanent, Sir.

And what is impermanent, is that pleasant or unpleasant?

Unpleasant, Sir.

Then is that which is impermanent, unpleasant, and subject to change fittingly regarded as, "This is mine; I am this; this is my self [etam mama, evoham asmi, eso me attā]"?

Surely not, Sir.

So also is it with feeling (vedanā), perception (sañ $\tilde{a} \bar{a})$, the conditioning factors (sankhāarā), and consciousness (viññāna).$^{43}$

The recognition that none of the five constituents are the self engenders disgust (nibbindati; Skt. niṣ $+\sqrt{ }$ vid) for them. Turning away from them, the ideal disciple (ariyasāvako) becomes detached (virajjati); being detached he is liberated (vimuccati) from the cycle of rebirth. ${ }^{44}$

As many interpreters have noted, in passages like this the Buddha

\footnotetext{
${ }^{40}$ Richard Gombrich, "The Buddha and the Jains: A Reply to Professor Bronkhorst," Asiatische Studien/Études Asiatiques 48, no. 4 (1994): 1081, and How Buddhism Began, 42.

${ }^{41}$ This is how Collins (Selfless Persons, 97) translates the title.

${ }^{42}$ Here I refer to "the Buddha" as portrayed in the Pāli Suttas, without presuming that this portrayal corresponds-or fails to correspond—to the extra-textual, "historical" Sākyamuni Buddha, who I fear, pace Gombrich (What the Buddha Thought, 17, 95-96), will forever remain largely inaccessible to us.

${ }^{43}$ Swāmī Dwārikādās Shāstrī, ed., The Saṃyuttanikāyapāli, vol. 2. (Varanasi: Bauddha Bharati, 2000), 829; cf. F. L. Woodward, trans., The Book of the Kindred Sayings (Sanyutta-Nikāya), pt. 3 (London: Pali Text Society, 1917), 59-60. On the translation of the five khandhas (rupa,

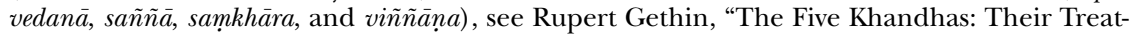
ment in the Nikàyas and Early Abhidhamma," Journal of Indian Philosophy 14 (1986): 36-37.

${ }^{44}$ Sāstri, The Saṃyuttanikāyapāli, 830.
} 


\section{The Journal of Religion}

does not explicitly deny the existence of the self. ${ }^{45}$ Indeed, the Buddha's teaching here presupposes the concept of the atta as permanent (nicca) and blissful (sukha). ${ }^{46}$ More specifically, the passage presupposes the dichotomy in earlier Vedic-Upanișadic speculation between, on the one hand, the nonvalued impersonal component parts of the phenomenal self and, on the other, the animating principle of those constituents, the purusa or atman, which is the source of whatever value the former have. ${ }^{47}$ By being dissociated from the idea of self, these constituents are drained of value. ${ }^{48}$ Here we note that the concept of the $a t t \bar{a}$, like those of dhamma, ariya, and brähmana in the examples above, retains a positive valence; indeed, without this positive valence the passage does not even make sense.$^{49} \mathrm{~A}$ line of modern interpreters, betraying the influence of a once fashionable universalist ideology that regards Hinduism and Buddhism as teaching the same fundamental truth,${ }^{50}$ have drawn the further inference that the Buddha's teaching here implies a belief in or, better, an experiential awareness of ${ }^{51}$ the existence of a transcendental $\bar{a} t m a n .{ }^{52}$ In the Anattalakkhana Sutta, we are led to infer, the Buddha taught a version of the later Vedāntic doctrine of àtmānātmaviveka, the discrimination of the true self from the physical and psychological entities

\footnotetext{
${ }^{45}$ Johannes Bronkhorst, Buddhist Teaching in India (Boston: Wisdom, 2009), 24; Oetke, "Ich" und das Ich, 89, 153; Thomas, History of Buddhist Thought, 101 n. 2; cf. K. R. Norman, "A Note on Attā in the Alagaddūpama-Sutta," in Studies in Indian Philosophy, ed. Dalsukh Malvania and Nagin J. Shah (Ahmedabad: L. D. Institute of Indology, 1981), 28. In the Alagaddūpama Sutta, however, he comes extremely close. Thus Norman concludes his article on atta in the Alaggaddūpama Sutta with the remark "I think it is correct to conclude that by implication, if not explicitly, the Buddha denied the existence of the permanent individual self" (28).

${ }^{46}$ Norman, "A Note on Attā in the Alagaddūpama-Sutta," 22. Oetke ("Ich" und das Ich, 161) observes that while such statements imply the idea of the atman, they do not necessarily imply its existence.

${ }^{47}$ Collins, Selfless Persons, 81-83, 113. According to Collins, this analysis of the human person can be traced back to the Vedic homologization of various parts of the human body to the cosmic counterparts into which the former are dispersed at death (49). Compare Stanislaw Schayer, "Kamalaśīlas Kritik des Puggalavāda," Rocznik orjentalistyczny 8 (1931-32): 70.

${ }^{48}$ Erich Frauwallner, History of Indian Philosophy, trans. V. M. Bedekar (Delhi: Motilal Banarsiddas, 1973), 152-53.

${ }^{49}$ Although the positive valence of attā here may simply reflect the Buddha's pragmatic, strategic appeal to the presuppositions of his audience.

${ }^{50}$ Kamaleswar Bhattacharya, L'Ātman-Brahman dans le Bouddhisme Ancien (Paris: École Française d'Extrême-Orient, 1973), 114, 137-40; Joaquín Pérez-Remón, Self and Non-self in Early Buddhism (New York: Mouton Publishers, 1980), 155; R. P. Chowdhury, "Interpretation of the 'Anatta' Doctrine of Buddhism: A New Approach," in Buddhist Sects and Philosophies, ed. Mahendra P. Mittal (Delhi: Originals, 2003), 200-201; Sarvepalli Radhakrishnan, Indian Philosophy, 2nd ed. (London, 1929), 385.

${ }^{51}$ See Bhattacharya, L'A'tman-Brahman, 22-24, 74-75.

${ }^{52}$ Pérez-Remón, Self and Non-self, 158 ff.; Bhattacharya, L'Ātman-Brahman, 65; Chowdhury, "Interpretation of the "Anatta' Doctrine," 198; C. A. F. Rhys Davids, "The Self: An Overlooked Buddhist Simile," Journal of the Royal Asiatic Society of Great Britain and Ireland 2 (April 1937): 260.
} 
falsely confused with it. ${ }^{53}$ And yet, such an interpretation, apart from audaciously, perhaps even arrogantly, disregarding the testimony of virtually the entire Buddhist tradition ${ }^{54}$ overlooks a subtle yet vital shift in emphasis away from the Brahmanical-Upanișadic preoccupation with the knowledge of the atman as the means to liberation to the active turning away from those things that are erroneously regarded as the self, ${ }^{55}$ that is, from a gnoseological quest for efficacious knowledge to a path of moral and spiritual discipline. As Johannes Bronkhorst argues, the Buddha's conspicuous silence on the nature of the attman indicates a rejection of what was one of the main soteriological options current at the time, namely, knowledge of a transcendental self that takes no part in action or its fruits (karma).$^{56}$ As we shall see presently, the idea of moral retribution in the theory of karma was one of the defining commitments of Buddhism. ${ }^{57}$

Within time, perhaps under the influence of the notion of efficacious knowledge in Vedic religion, ${ }^{58}$ the Buddhist tradition developed the notion that liberation could be brought about by a form of special knowledge or insight. In the earliest sources, the content of this liberating insight was identified with the Four Noble Truths. The awk-

\footnotetext{
${ }^{53}$ This connection is explicit in Chowdhury ("Interpretation of the 'Anatta' Doctrine," 200), implicit in Bhattacharya, L'Ātman-Brahman, and Pérez-Remón, Self and Non-self.

${ }^{54}$ See Steven Collins's harsh criticism of Pérez-Remón for the latter's decision to disregard the self-understanding of the living traditions of Buddhism ("Self and Non-Self in Early Buddhism: Review Article," Numen 29, no. 2 [December 1982]: 254, cf. 250-51, 271). I suspect that what is ultimately at stake in this "perennialist" line of interpretation is a refusal to recognize the legitimacy of an oppositional dimension of religion in general and of Buddhism in particular. Pérez-Remón (154) speaks pejoratively of the doctrine of "absolute" anattā as the product of the tradition's "ideological development" after the Buddha. Chowdhury ("Interpretation of the 'Anatta' Doctrine," 191) asserts that "a search for a school against which the Anattā doctrine was directed is bound to be futile." Bhattacharya (L'Átman-Brahman, 137) concludes his study with the judgment that "notre controverse n'est qu'une querelle de mots. . . . Il n'y a pas de contradiction entre ätman et anätman."

${ }_{55}^{55}$ Bronkhorst, Buddhist Teaching in India, 35.

${ }^{56}$ Ibid., 27, 123; cf. Bronkhorst, Two Traditions of Meditation in Ancient India (Stuttgart: Steiner, 1986), 52, 57, 95.

${ }^{57}$ Compare Etienne Lamotte's statement (cited in Gombrich, How Buddhism Began, 49) that "the doctrine of the act, karman, is the keystone of the entire Buddhist edifice." According to Lilian Silburn (Instant et cause [Paris: Vrin, 1955], 127, 163), the theory of karma served as the Middle Way between two extreme views, eternalism and annihilationism (śáśvatavāda and ucchedavāda, respectively), both of which shared a denial of the moral act and its consequences.

${ }_{58}$ Bronkhorst, Buddhist Teaching in India, 29-30; Lambert Schmithausen, "On Some Aspects of Descriptions or Theories of 'Liberating Insight' and 'Enlightenment' in Early Buddhism," in Studien zum Jainismus und Buddhismus, Gedenkschrift für Ludwig Alsdorf, ed. Klaus Bruhn and Albrecht Wezler (Wiesbaden: Steiner, 1981), 211, and "Zur Struktur der erlösenden Erfahrung im indischen Buddhismus," in Transzendenzerfahrung, Vollzugshorizont des Heils: Das Problem in indischer und christlicher Tradition, ed. Gerhard Oberhammer (Vienna: De Nobili Research Library, 5, 1978), 103.
} 
wardness of this identification-somewhat embarrassingly, the Four Noble Truths themselves do not mention ignorance as a cause of suffering-strongly suggests that this understanding of the Four Truths as the content of liberating insight was a later use of this teaching. ${ }^{59}$ According to Bronkhorst, the notion of liberating knowledge functioned as something of a placeholder, to be filled with whatever was regarded as the essential or fundamental teaching of Buddhism. ${ }^{60}$ Eventually the Four Noble Truths were supplanted by the teaching of Dependent Origination (Pā. paticcasamuppāda; Skt. pratityasamutpāda) as the most fundamental and soteriologically relevant of the Buddha's teachings ${ }^{61}$ In most of the so-called Hinayāna schools, the doctrine of dependent origination was in turn supplanted in this role by the doctrine of the nonexistence of a substantial self (nairātmya).$^{62}$ The belief in a substantial self came to be regarded as the basis of all forms of delusion and suffering. ${ }^{63}$ At the end of this development stands an idea that might be taken as a symbol of Buddhism's ironic stance vis-à-vis Brahmanism, namely, that "the rejection of the liberating knowledge of others becomes itself a liberating knowledge." ${ }^{64}$ From the centrality of the question of the self and its existence in the later Brahmanical-Buddhist debates, we might infer that apologetical issues were a major factor in this identification of the not-self doctrine with the content of liberating insight ${ }^{65}$ Indeed, one suspects that this soteriological promotion of the not-self doctrine coincides with its assuming the role of a symbolic marker of opposition to Brahmanical thought. ${ }^{66}$

\footnotetext{
${ }^{59}$ Schmithausen, "On Some Aspects," 208.

${ }^{60}$ Bronkhorst, Two Traditions of Meditation in Ancient India, 96. But see Gombrich, "The Buddha and the Jains," 1073.

${ }^{61}$ Franz Bernhard, "Zur Interpretation der Pratītyasamutpāda-Formel," Wiener Zeitschrift für die Kunde Süd- und Ostasiens, vols. 12-13 (1968-69): 55. Based on a philological analysis and comparison of various narratives of the night of the Buddha's enlightenment, Ernst Waldschmidt ("Die Erleuchtung des Buddha," in Von Ceylon bis Turfan [Göttingen: Vandenhoeck \& Ruprecht, 1967], 228) concludes that those texts in which an insight into the chain of dependent origination immediately precedes the Buddha's enlightenment (during the third watch of the night) are later than those texts in which the Buddha attains enlightenment upon having an insight into the Four Noble Truths.

${ }^{62}$ Schmithausen, "On Some Aspects," 212; Bronkhorst, Buddhist Teaching in India, 31.

${ }^{63}$ See Schmithausen, "Zur Struktur der erlösenden Erfahrung im indischen Buddhismus," 113; Silburn, Instant et cause, 160.

${ }^{64}$ Bronkhorst, Buddhist Teaching in India, 28, cf. 104.

${ }^{65}$ As Wilhelm Halbfass (Karma und Wiedergeburt im indischen Denken [Munich: Diederichs, 2000], 192) observes, "the rejection of the Buddhist 'doctrine of not-self' was for centuries one of the chief concerns of the Hindu philosophical schools."

${ }^{66}$ I believe this hypothesis goes a long way to meeting Gombrich's ("The Buddha and the Jains," 1073) objection to Bronkhorst's "placeholder" theory, namely, that it is implausible "to claim that Buddhism began as a teaching without a doctrine. Has any religion ever spread without a doctrine?" There always was-obviously_content to Buddhist teaching, but what was doctrinally important to Buddhism-what marked the distinctiveness of Buddhism vis-à-
} 
The emergence of the not-self doctrine as a marker of Buddhist identity might be compared with the analogous role of the doctrine of the divinity of Christ in the development of Christian theology. As Daniel Boyarin argues, the understanding of Christ as a second divine principle (as the Word, or Logos, of God) did not become a touchstone of Christian identity (and, concomitantly, the rejection of such a claim in the Jewish) until the third or even fourth century, when a clear borderline was formed between the Christian and Jewish communities. ${ }^{67} \mathrm{Up}$ until this time there were, on the one hand, non-Christian Jews who believed in a second divine principle (God's Word, Wisdom, or Son) mediating between a transcendent Godhead and the material world and, on the other, followers of Jesus who held that Christ was simply a name for the manifestation of a single divine personality. ${ }^{68}$ In the example of the relation between Buddhism and Brahmanical thought, by contrast, the separation was likely there from the beginning. Nevertheless, the idea of not-self may not yet have acquired the role of a boundary marker in the period of Buddhism reflected in the Pāli Nikāyas. ${ }^{69}$

\section{RECONCILING THE ANATTĀ DOCTRINE WITH KARMA THEORY}

One indication that a concept has been motivated in part by a need to mobilize communal identity is a tension with everyday experience and/ or other defining tenets of a belief system. ${ }^{70}$ The ideological dimension

vis its proximate rivals-probably depended on the ideological landscape of a particular time and place. On the way in which the central teachings of an intellectual tradition are largely determined by a changeable complex of social oppositions, see Randall Collins's wide-ranging study of the social structure of intellectual life in a variety of historical-cultural contexts, The Sociology of Philosophies (Cambridge, MA: Harvard University Press, 1998). I am grateful to one of my anonymous reviewers for bringing Collins's book to my attention.

${ }^{67}$ Daniel Boyarin, Border Lines (Philadelphia: University of Pennsylvania Press, 2004). Up through the second century, and in some areas perhaps much later, Christianity can be regarded as a strand of Hellenistic Judaism, albeit one that separated itself from other strands by attaching special importance to Jesus (see Birger A. Pearson, "The Emergence of Christian Religion," in The Emergence of Christian Religion: Essays on Early Christianity [Harrisburg, PA: Trinity Press International, 1997], 15). One could argue that even after the borderline was established, the divinity of Christ was not unambiguously affirmed in Christian circles until the official condemnation of Arianism in the Council of Nicaea in 325.

${ }^{68}$ Boyarin, Border Lines, 90, 92.

${ }^{69}$ This is not to suggest, however, that the notion of the nonexistence of the atman was a falsification of early "Nikāyan" Buddhism (as Pérez-Remón, Bhattacharya, and others presume), any more than the notion of the divinity of Christ was a falsification of early Christian teaching. Such a position rests on the questionable assumption that the identity sustaining doctrines of a religious community are only legitimate if they are self-generated, in other words, that a conception of religious identity is somehow inauthentic if it can be shown that it developed in active and often conflictual relations with rival communities.

${ }^{70}$ See Martin Southwold, "Buddhism and the Definition of Religion," Man 13, no. 3 (September 1978): 374-76, on the usefulness of "empirically indeterminate" doctrines in demarcating cultural communities and strengthening their identity and solidarity. 
of the anatta doctrine-here I use the term ideology in a neutral, rather than pejorative, sense to denote a discourse that functions to mobilize a social group-manifests itself in a tension not only with the everyday experience of selfhood (the sense of individuality and of the continuity of personal experience through time) but also, and perhaps more challenging from a purely doctrinal standpoint, with the ideas of karma and rebirth. Much of the intellectual labor of Buddhist thinkers through the ages has been devoted to answering the question posed by virtually every beginning undergraduate student of Buddhism, namely, if there is no self, who or what is it that is reborn, and to whom or what does karma adhere?

As mentioned above, the notions of karma and rebirth-or, in other words, the belief in the moral retribution of actions within a time frame extending beyond the present life span-together comprise one of the defining commitments of Buddhism. In the Sāmañnaphala Sutta, the Buddha affirmed the theory of karma against a colorful group of six contemporary teachers, each of whom, from various theoretical perspectives, denied it. The various teachings represented by this motley group can be classified into two basic categories: determinism and materialism. ${ }^{71}$ The determinist doctrine, known under the general heading of Ājīivism in India, is exemplified by Makkhali Gosala, who held that "the attainment of any given condition, of any character, does not depend either on one's own acts, or on the acts of another, or on human effort." ${ }^{\prime 2}$ Another member of this group, Ajita Kesakambalī, exemplifies the materialist doctrine. He taught that the human being consists without remainder of four elements that are absorbed into their respective cosmic counterparts upon death. ${ }^{73}$ What these doctrines of determinism and materialism have in common is a denial of karmic retribution: the

\footnotetext{
${ }^{71}$ Collins, Selfless Persons, 35. The six teachers can be further subdivided: The first member of this group, Pūraṇa Kassapa, taught an antinomian doctrine ("to him who kills a living creature, who takes what is not given, who breaks into houses, . . . who commits robbery, or adultery, or who speaks lies, to him thus acing there is no guilt" [Müller, Sacred Books of the Buddhists, 69]); the sixth, Sañjaya Belatthiputta, agnosticism. The fifth, Nigaṇṭha Nātaputta, can be identified with Vardhamāna Mahāvīra, the founder of Jainism. See A. L. Basham, History and Doctrines of the Äjivikas (Delhi: Motilal Banarsidass, 1981), 10-18.

${ }^{72}$ Müller, Sacred Books of the Buddhists, 71; cf. Swāmī Dwārikādās Shāstrī, ed. and trans., Dīghanikāyapāli, pt. 1, Silakkhandha Vagga (Varanasi: Bauddha Bharati, 1996), 59, lines 8-9: "nathi attakāre, nathi parakāre, nathi purisakāre." The doctrines of three of the six teachers mentioned in the Sāmaññaphala Sutta, namely, Pūraṇa Kassapa, Makkhali Gosāla, and Pakudha Kaccāyana, are associated with later Ājīivism (Basham, History and Doctrines of the Äjìvikas, 17).

${ }^{73}$ Shāstrī, Dìghanikāya, 61, lines 5-7: "cātumahābhūtiko ayaṃ puriso; yadā kālaṃ karoti, pathavī pathavikāyam anupeti anupagacchati, āpo āpokāyaṃ anupeti anupagacchati; tejo tejokāyaṃ anupeti anupagacchati; vāyo vāyokāyam anupeti anupagacchati; ākāsaṃ indriyāni sankamanti." Compare Müller, Sacred Books of the Buddhists, 73-74.
} 
former by denying any influence of (intentional) action on future existential states, the latter by denying an afterlife in which such karmic effects could be realized. ${ }^{74}$

It was by affirming, against contemporary materialist and determinist currents of thought, the ideas of karma and rebirth, while at the same time denying, against both Brahmins and Jains, the idea of a permanent self, that Buddhism carved out a niche for itself in its ancient Indian religious milieu. In other words, it established a distinctive identity by waging an ideological war on two fronts, against the materialists and Ajjivikas on the one side and the Brahmins and Jains on the other. ${ }^{75}$ Buddhism rather tendentiously represented its relationship to its two principal adversaries with the rhetoric of the Middle Way: the Brahmins and the Jains with their theory of the self ( $\bar{a}$ tmavāda) represented the extreme of eternalism (Pā. sassatavāda; Skt. śāsvatavāda), the materialists and the Ajivikas with their denial of an afterlife the extreme of annihilationism (ucchedavāda).

In defining itself over against these two adversaries, early Buddhism committed itself to the difficult task of affirming the ideas of karma and rebirth without the support of the notion of a transmigrating entity or principle. ${ }^{76}$ Such was the aim of "the oldest work to express the denial of the soul in detail and in full clarity," the Milindapañha ("Milinda's Questions"). ${ }^{77}$ This dialogue between the Graeco-Bactrian king Milinda (Meneander, ca. $250 \mathrm{BCE}$ ) and the Buddhist monk Nāgasena is essentially an extended reply to the king's objection to the proposition, baldly stated by Nāgasena at the outset of the dialogue, that "no person is found here" ${ }^{\text {78 }}$ Alluding to the heretical teaching of Ajita Kesakambalī mentioned above, the king states the most fundamental of the many unacceptable consequences of this denial of the self: "There is no fruit or ripening of deeds well or ill done." ${ }^{79}$ In the course of the dialogue, Nāgasena attempts to disabuse the King of the latter's quite understand-

\footnotetext{
${ }^{74}$ The extreme sarcasm of the Buddha against the followers of Makkhali, as compared to his somewhat milder attitude toward the Brahmins and their rites, testifies to the importance of karma for the early Buddhist tradition. See Silburn, Instant et cause, 161.

${ }_{75}^{75}$ Halbfass, Karma und Wiedergeburt, 184.

${ }^{76}$ Ibid., 33, 107.

${ }^{77}$ Erich Frauwallner, Die Philosophie des Buddhismus (Berlin: Akademie, 1969), 65. Oetke ("Ich" und das Ich, 180, 185), however, argues that the Milindapañh's rejection of a puggala existing separately from the five khandhas falls short of an absolute denial of a self.

78 "na h'ettha puggalo upalabbhati"; V. Trenckner, ed. The Milindapañho (London: Pali Text Society, 1962), 25. See also Kapstein, Reason's Traces, 79-81, for an excellent discussion of the locution "no self/person is found here" in the Buddhist tradition.

${ }^{79}$ Trenckner, Milindapañho, 25, line 27; cf. Shāstrī, Dīghanikāya, 61, line 2: "natthi sukaṭadukkațānam kammānaṃ phalam vipāko"; the English translation in the text is from I. B. Horner, Milinda's Questions, vol. 1 (London: Luzac, 1963), 35.
} 
able concern that the anatta doctrine is incompatible with the law of moral retribution and the idea of rebirth. Nāgasena does this mainly through a series of engaging images and analogies. In one of the text's more memorable images, the monk persuades the king that rebirth can occur without the presupposition of an enduring, changeless self by comparing the process of rebirth to a flame that burns continuously through the night. ${ }^{80}$ Through its various illustrations, the text shows that the notion of a causal connection between the discrete members of a temporal series suffices to preserve the notion of moral responsibility. It is because the mangoes planted by one person are causally connected (though not, according to the Buddhist doctrine of momentariness [kșanavāda], substantively identical) to those later stolen by another that the latter is subject to punishment. ${ }^{81}$ This notion of a causal series, which the Milindapañha is content to suggest through a series of images and analogies, finds more developed articulation in Vasubandhu's Abhidharmakośa (fifth century CE). In the third chapter of this work, Vasubandhu argues that the chain of dependent origination (Pā. paticcasamuppāda; Skt. pratityasamutpāda) suffices, without the additional assumption of a substantial self, to explain the mechanism of karma and rebirth. ${ }^{82}$ The doctrine of dependent origination-the doctrine that, as expressed in the shorthand Pāli formula, "When that is, this becomes; from the arising of that, this arises; when that is not, this is not; from the cessation of that, this ceases" ${ }^{13}$ - takes the place of the self as the underlying presupposition of karma and samsāra. This doctrine, however, particularly in its developed formulation as a circular chain of twelve links, is obscure, as even the Buddha himself is said to have admitted ${ }^{84}$ Its obscurity, one suspects, has as much to do with the intractability of the problem for which it is the proffered solution, namely, explaining the mechanism of rebirth without the assumption of a transmigrating person or self, ${ }^{85}$ as it does with the awkwardness and

${ }^{80}$ Trenckner, Milindapañho, 40, lines 20-32; Horner, Milinda's Questions, 55-56, cf. 97.

${ }^{81}$ Trenckner, Milindapañho, 46, lines 16-29; Horner, Milinda's Questions, 64, cf. 98.

${ }^{82}$ Alexis Sanderson, "The Sarvāstivāda and Its Critics: Anātmavāda and the Theory of Karma," in Buddhism into the Year 2000 (Los Angeles: Dhammakaya Foundation, 1994), 37; Frauwallner, Die Philosophie des Buddhismus, 77.

83 "imasmim sati idạ̣ hoti, imassuppādā idam uppajjati; imasmin asati idạ̣ na hoti, imassa nirodhā idam nirujjhati." See, e.g., M. Leon Feer, ed., Samyutta-Nikāya, pt. 2 (London: Pali Text Society, 1960), 65, lines 5-7. Compare Shāstrī, Abhidharmakośa, pt. 2, 432, lines 14-15.

${ }^{84}$ Frauwallner, History of Indian Philosophy, 165-66. In the Mahānidāna Sutta, the Buddha reproves Ānanda for the latter's opinion that the doctrine is clear and only appears deep (gambhīra).

${ }^{85}$ See Collins, Selfless Persons, 108: "When taken as a whole, it [the twelvefold formula of Dependent Origination] expressed, symbolically, the idea of 'the round of rebirth' without the reincarnating self or person which Brahmanical thinking had postulated." 
complexity-owing to its probable composite nature-of its scholastic formulation. ${ }^{86}$

One indication of the intractability of the karma-without-self problematic is the recurrence, at several points in the history of Buddhism, of various functional equivalents of the self, many of which were shrewdly denounced by rival Buddhist sects as attempts to smuggle the self into Buddhism through the back door. ${ }^{87}$ The most notorious of these was the notion of the person (Pā. puggala, Skt. pudgala) put forward by the Vātsīputrìya-Sāmmitìya schools early on in the history of Buddhism. ${ }^{88}$ In order to explain the mechanism of karma and rebirth, as well as the phenomena of self-consciousness and memory, these so-called Personalist (Pā. Puggalavādin; Skt. Pudgalavādin) schools posited a personal principle that was neither separate from nor identical with the five skandhas. ${ }^{89}$ They compared the relation of the person to the aggregates to

${ }^{86}$ Frauwallner (History of Indian Philosophy, 166-68) proposed the plausible hypothesis that the twelvefold sequence is the result of the mechanical addition of what were originally two parallel sequences. See also Bernhard, 56-57, 61-63. Much of the obscurity can be traced to the ambiguity of viñ̃anna, "consciousness," the third link in the chain. On the one hand, viñ $\tilde{a}$ ñ is included among the five aggregates that are declared impermanent and "selfless" (Frauwallner History of Indian Philosophy, 160, 162). On the other hand, viññana emerged as the most prominent of the aggregates; it was the constituent of the personality serving as the link between different existences (Bareau, "La notion de personne," 91; cf. Lambert Schmithausen, "Critical Response," in Karma and Rebirth: Post-classical Developments, ed. Ronald W. Neufeldt [Albany: SUNY Press, 1986], 217). This latter role is implicit in the sequence of links in the twelvefold sequence of dependent origination. Viñãana immediately precedes näma-rüpa ("name and form"), the physical and psychical manifestation of a new birth. The viñ̃ana that enters into the mother's womb corresponds, in other Indian systems, to the "fine body" (sükșmamśariram) that develops into the fetus (Frauwallner, History of Indian Philosophy, 162-63). To the extent that the doctrine of dependent origination is ambiguous about the role of viñ̃ana in the process of rebirth, it begs the question of a transmigrating principle.

${ }^{87}$ Edward Conze, Buddhist Thought in India: Three Phases of Buddhist Philosophy (London: Allen \& Unwin, 1962), 132: "So strong indeed is the practical and theoretical need for the assumption of a permanent factor in connection with the activities of a 'person,' that in addition to the Pudgalavādins, other schools also felt obliged to introduce it more or less furtively in a disguised form, though the word 'self' remained taboo at all times." The first of these could have been the viññana ("consciousness"), which functioned as the vehicle of rebirth in the cycle of dependent origination notwithstanding the fact that, in the Mahātạ̣hāsankkhaya Sutta, the Buddha, rejected, in the strongest terms, the "evil opinion" that viñ̃̃ana was the vehicle of rebirth. See Thomas, History of Buddhist Thought, 103; Schmithausen, "Critical Response," 217.

${ }^{88}$ The Sāmmatìya was probably the most influential branch of the Vātsīputrīya, soon even eclipsing the latter. See L. S. Cousins, "Person and Self," in Buddhism into the Year 2000 (Los Angeles: Dhammakaya Foundation, 1994), 27; Bareau, Les sects bouddhiques du petit véhicule (Saïgon: École Française d'Extrême-Orient, 1955), 115. Bareau dates the appearance of the Vātsīputrìya at the third century BCE (14) and that of the Sammatìya at a century before or after the common era (121).

${ }^{89}$ Thich Thiên Châu, "Les réponses des Pudgalavādin aux critiques des écoles bouddhiques," Journal of the International Society for Buddhist Studies 10, no. 1 (1987): 40-41; Leonard Priestley, Pudgalavāda Buddhism (Toronto: University of Toronto Press, 1999), 51; Silburn, Instant et cause, 246-47. 
that of a fire to its fuel..$^{90}$ They intended their concept of the person as a Middle Way between the extremes of eternalism, represented by the atmavāda of the non-Buddhist schools, and annihilationism, which they associated with the so-called skandhavāda, the rival Buddhist view that the person exists only nominally. ${ }^{91}$ Against the polemical characterization put forward by rival schools like the Theravāda-the historical victors of this early intra-Buddhist struggle-it is important to emphasize this point that the Pudgalavādins distinguished their concept of the pudgala from the ätmavāda of the non-Buddhists. ${ }^{92}$ Of course, rival Buddhist schools rejected the distinction between the pudgalavāda and the non-Buddhist ătmavāda as specious; the pudgala was merely the Brahmanical ätman under another name. ${ }^{93}$ As this criticism gained currency, the Pudgalavādins came to be regarded by other Buddhists as outsiders. ${ }^{94}$ Another notable example of a Buddhist concept that assumed some of the functions of a self was the "storehouse consciousness" (älayavijñana) of the later Mahāyānist Cittamātra school. ${ }^{95}$ The storehouse conscious-

${ }^{90}$ See Priestley, Pudgalavāda Buddhism, 165-86. The fuel fire comparison, however, is not found in the earliest presentations of Puggalavādin teaching, such as the Kathavatthu. See Cousins, "Person and Self," 19.

${ }^{91}$ Châu, "Les réponses des Pudgalavādin," 39; Silburn, Instant et cause, 247; Cousins, "Person and Self," 18.

${ }^{92}$ Schayer, "Kamalaśîlas Kritik," 72 n. 23; James P. McDermott, "Karma and Rebirth in Early Buddhism," in Karma and Rebirth in Classical Indian Traditions, ed. Wendy Doniger O'Flaherty (Berkeley: University of California Press), 168. This they did by refusing to characterize the pudgala as unconditioned (asamskrta). Specifically, they assigned the pudgala its own, unique category of being (dharma), distinct from the three categories of conditioned (samskrta) dharmas (past, present, and future), and the one unconditioned dharma, nirvana. See Châu, "Les réponses des Pudgalavādin," 42; Priestley, Pudgalavāda Buddhism, 79.

${ }^{93}$ See, e.g., Kamalśíla's Pañjikā on Śāntarakșita's Tattvasamgraha (Schayer, "Kamalaśīlas Kritik," 72). The Puggalavādins rendered themselves particularly vulnerable to this charge by using terms like ätman, jivva, and purușa as equivalents for their concept of the pudgala (Priestley, Pudgalavāda Buddhism, 81-83, 187; see also Joseph Walser, Nāgārjuna in Context (New York: Columbia University Press, 2005), 201. This might suggest that the Personalist Controversy played an important role in the development of the doctrine of not-self. Indeed, according to Thomas (History of Buddhist Thought, 101), the rejection of the atman appears to have become more intense with the growth of the controversy. Or perhaps we could infer that in reacting against it, "orthodox" Buddhism radicalized its understanding of the anātmavāda, understanding it as skandhavāda, the view that the self or person referred to no reality irreducible to, or existing apart from the five skandhas.

${ }^{94}$ See Silburn, Instant et cause, 246: "Parmi les Buddhistes les Vātsīputrīya côtoient de si près l'hérésie que certains Buddhistes n’hésitent pas à les ranger parmi les infidels (Tīrthika)." Significantly, however, this does not appear to be the case with the Katthāvatthu, the earliest source for Pudgalavāda views. That the Kathāvatthu appears to recognize the Pudgalavāda as a rival interpretation of the Buddha's teaching, albeit an incorrect one, suggests that at this time, the interpretation of anātmavāda was still rather more fluid; only when anātmavāda was more or less identified with skandhavāda were the Pudgalavādins regarded as being outside the pale.

${ }_{95}^{5}$ Lambert Schmithausen, Ālayavijñana: On the Origin and the Early Development of a Central Concept of Yogācāra Philosophy (Tokyo: International Institute for Buddhist Studies, 1987), 3. 
ness served as a repository for the "seeds" linking previous acts with the personal experiences ostensibly resulting therefrom. ${ }^{96}$ Like the earlier Pudgalavādins, the Cittamātra tradition strenuously denied the charge that their storehouse consciousness was merely the self under a different name. ${ }^{97}$

From these examples, it would appear that the ideas of karma and rebirth presuppose some functional equivalent of the self, that is, some connecting link between one karmically determined existence and another. This is not to say, of course, that karma theory presupposes the permanent, unchanging self of Brahmanical-Upanișadic thought. And yet the polemical context in which Buddhism developed the not-self doctrine, to the extent that this doctrine functioned as a boundary marker with respect to Brahmanism, discouraged nuanced distinctions between different concepts of selfhood. Perhaps one could venture the generalization that a strong interest in demarcation encourages the formation of binary oppositions like self versus not-self, as opposed to relative distinctions like self and person. ${ }^{98}$ Polemical demands thus prohibited Buddhist thinkers from using the terms atta and puggala in technical contexts, even in those dealing with karmic retribution and rebirth, where the use of such terms would appear to be almost unavoidable. The situation has a close parallel in the realm of politics, where partisans are sometimes forced to adopt awkward circumlocutions in their effort to avoid terms that have been successfully claimed by their adversaries.

According to Conze (Buddhist Thought in India, 131), the Pudgalavādins were the forerunners of the Yogacārins with their storehouse consciousness. But see Schayer's ("Kamalaśīlas Kritik," 71) reservations about the assumption of a close parallel between the two schools.

${ }_{96}$ Paul Williams, Mahāyāna Buddhism (New York: Routledge, 1989), 91.

${ }^{97}$ Ibid. Other examples of functional equivalents to self and person include: the Sarvāstivāda concept of präpti, "possession," the unifying principle that channels a given karmic effect to a particular sequence of dharmas (corresponding to the empirical personality) and not others (see Conze, Buddhist Thought in India, 141; Bronkhorst, Buddhist Teaching in India, 91-92; Schmithausen, "Critical Response," 219); Vasubandhu's concept of the "intermediate state" (antarā bhäva) between death and rebirth, the "karmically determined combination of skandhas" that links one existence to another (McDermott, "Karma and Rebirth," 170-71); the Abhidharma concept of bhavariga, conceived of as "a transmitting factor in rebirth" (see Bruce Matthews, "Post-Classical Developments in the Concepts of Karma and Rebirth in Theravāda Buddhism," in Neufeldt, Karma and Rebirth, 128, 130); and, finally, the Mahāyāna concept of the tathāgatagarbha ("Buddha nature"). This latter not only fulfills some of the functions of the self, particularly in safeguarding Buddhist teaching from nihilism, but is also, strikingly, sometimes (particularly in the Mahāparinirvānasūtra) called àtman, albeit in a qualified sense (Ruegg, Buddha-Nature, 19-26; Williams, Mahāyāna Buddhism, 98-100). Williams (Mahāyāna Buddhism, 100) speculates that the use of the term àtman in texts like the Mahäparinirvānasūtra reflects the resurgence of Hindu culture in the Gupta period.

${ }^{98}$ That being said, one does not have to accept uncritically the traditional view that doctrinal development unfolds according to an inner logic that overrides historical contingencies. Given a different set of historical conditions, I do not think it inconceivable that the Puggalavādins could have won the day, for they were able to present their puggalavāda plausibly in terms of the Middle Way and thus reject the sassatavāda of the Brahmanical doctrine of the $\bar{a} t m a n$. 


\section{The Journal of Religion}

We have seen, then, that the Buddhist tradition, in its effort to differentiate itself from Brahmanical thought on the one side and Ājivikamaterialist thought on the other, found itself faced with the task of reconciling what on the surface might appear to be two contradictory claims, namely, the doctrine of not-self, understood in a more or less absolute sense, and the ideas of karma and rebirth. It was thus in response to this problematic of rebirth-without-self that the Buddhist tradition developed a range of concepts, most notably the doctrine of dependent origination, whose subtlety and profundity might easily appear, from a less charitable standpoint, as obscurity and ambiguity. ${ }^{99}$ Here we might draw an illuminating parallel with the development of the Christian doctrine of the Trinity. This doctrine is also the product of the need to reconcile two prima facie contradictory claims, namely, the divinity of Christ and monotheism. Each of these claims, moreover, like those of not-self and karma in Buddhism, served to demarcate the early Church from rival religious traditions; together they established a distinctive sense of identity for early Christianity in its original Hellenistic milieu. According to the admittedly stylized presentation of the fourth-century Cappadocian theologian Gregory of Nyssa, the affirmation of Christ or the Word as a distinct divine hypostasis distinguishes Christianity from Judaism, while the affirmation of the unity of the divine nature distinguishes Christianity from the polytheism of the Greeks. ${ }^{100}$ The problematic of reconciling biblical monotheism with the divinity of Christ was eventually resolved, after a tumultuous period of confusion, uncertainty, and controversy, with the three-persons-in-onesubstance formula that gives orthodox expression to this central Christian mystery. In order to avoid the pitfalls of tritheism (i.e., the belief in three separate divine principles), on the one side, and monarchianism (the denial that the Son and Spirit are independent and fully divine principles), on the other, the formula depends on a manufactured-critics would say specious-distinction between hypostasis ("person") and ousia ("substance"). ${ }^{101}$

\footnotetext{
${ }^{99}$ Perhaps the ultimate testimony to the difficulty of reconciling the anattā doctrine with karma theory is the fact that most Buddhists in places like Śri Lanka and Burma, concerned as they are with merit and karma, apparently do not understand its "proper," official meaning (Gombrich, Buddhist Precept and Practice, 84-87; Spiro, Buddhism and Society, 88-89).

${ }^{100}$ Edward R. Hardy, ed., Christology of the Later Fathers (Philadelphia: Westminster Press, 1954), 274: "The teaching of the Jew is invalidated by the acceptance of the Word and by belief in the Spirit; while the polytheistic error of the Greeks is done away, since the unity of the nature cancels the notion of plurality."

${ }^{101}$ Hypostasis and ousia were not clearly distinguished before the fourth century. Indeed, they were often used synonymously, as, for example, by the third-century theologian Origen. See R. P. C. Hanson, The Search for the Christian Doctrine of God (New York: Clark, 1988), 18190, and cf. 66.
} 
Up to this point, our analysis may point to a cynical conclusion: ideological demands force religious communities to develop and profess obscure and ambiguous doctrines that, to the extent that they are intelligible, stand in tension with everyday experience. And yet, it is thanks to the pressure exerted by these same ideological demands, I would now like to suggest, that such doctrines can function as leverage points from which everyday experience can be transformed in productive ways.

\section{TRANSFORMATIVE DISCOURSE AND AUTHORITY}

In this final part of the essay, I would like to reflect on the transformative dimension of the not-self doctrine in light of the thesis, developed above, that this doctrine was motivated in large part by an interest in mobilizing Buddhist identity against the Brahmanical order. In his analysis of anattā in the Theravāda tradition, Steven Collins makes an important distinction between the doctrinal acceptance and the psychological realization of this teaching. These two modalities of anatt $\bar{a}$ correspond to different stages in an aspirant's spiritual progress. In the initial stages of one's spiritual development, an acceptance of the notself doctrine intercepts the natural tendency to convert the experienced sense of "I" into a theoretical belief in the self. ${ }^{102}$ The loss of this "personality belief" (sakkāyaditthi) marks the attainment of "stream winner" status, that is, the status of one who, by virtue of having set forth on the Path, is certain to attain enlightenment after a limited number of rebirths. ${ }^{103}$ Ideally, particularly if this acceptance of the not-self doctrine is incorporated into a regimen of meditative self-analysis, this spontaneous sense of "I" gradually weakens as it is deprived of theoretical support. ${ }^{104}$ As mentioned above, the aim of insight meditation is the reclassification of experience in terms of devalued, impersonal categories. This redescription of experience strips everyday experiences and attachments of the names that would otherwise secure and stabilize them in being. The eventual loss of the autonomic sense of ego-which loss marks the experiential realization of anattā - constitutes the achievement of arhat status, the attainment of nirvana in this life. ${ }^{105}$ When the contents of consciousness are no longer experienced in relation to a

${ }^{102}$ Collins, Selfless Persons, 93-94.

${ }^{103}$ Ibid., 94.

${ }^{104}$ Ibid., 95.

${ }^{105}$ Ibid., 94. Up until this point, one can affirm the truth of anatta and yet still continue to experience oneself as an "I," as illustrated by the story of the elderly monk Khemaka (M. Leon Feer, ed., Samyutta-Nikāya, pt. 3 [London: Pali Text Society, 1960]), who admits that despite recognizing each of the five khandhas to be anattā, he continues to experience a residual sense of "I am." Compare Collins, Selfless Persons, 95. 
putative self as their agent or bearer, one's experience of reality has obviously undergone a profound transformation.

Collins makes an astute observation about the anattā doctrine that provides a clue to the link between its spiritual-transformative and ideological-political dimensions. The doctrine, he says, functions as a "linguistic taboo" in technical discourse ${ }^{106}$ where he understands "taboo" to refer, following Franz Steiner's definition, to "all the social mechanisms of obedience which have a ritual significance." 107 The idea of taboo highlights the "air of ineluctable and incontestable necessity" that the idea of not-self has, for example, in the dialogue between Milinda and Nagāsena in the Milindapañha. ${ }^{108}$ Collins, moreover, observes that this taboo functions on both of the two levels that I am interested in bringing into relation: first, it "forms part of a particular style of meditative self-analysis"; second, it "preserves the identity and integrity of Buddhism as an Indian system separate from Brahmanism."

These two functions, I would now like to suggest, do not simply run alongside each other in parallel tracks; rather, they are intrinsically linked. To see the relation between them, we must first recognize that the anatta doctrine can be used to overcome deeply ingrained habits of speech and mind only to the extent that it is imbued with a moral power transcending the individual practitioner. The acceptance and interiorization of a doctrine so manifestly "against the current" (patisotam) invites an analysis in terms of Durkheim's venerable distinction between the individual and collective dimensions of human experience, between the psychological and the sociological. What Durkheim writes about the phenomenology of moral obligation would apply, a fortiori, to the Buddhist reclassification of experience in terms of impersonal categories: "Our élan and aspiration are accompanied by discipline and effort. Even when we carry out a moral act with enthusiasm we feel we dominate and transcend ourselves, and this cannot occur without a feeling of tension and restraint. We feel that we do violence to a part of our being." ${ }^{109}$ Another way of expressing this idea is that the use of the notself doctrine to restructure one's experience of self and world presupposes a structure of authority, which is manifest in the doctrine's taboo character. This authority, moreover, is constituted by the recognition of a social group. ${ }^{110}$

${ }^{106}$ Ibid., 12, 77, 149, 183. 183.

${ }^{107}$ Franz Steiner, Taboo (London: Cohen \& West, 1956), 20; cited in Collins, Selfless Persons,

${ }^{108}$ Collins, Selfless Persons, 183.

${ }^{109}$ Emile Durkheim, Sociology and Philosophy (New York: Free Press, 1974), 45.

${ }^{110}$ The claim that the collective is the ultimate source of the authority of the anatta doctrine is obviously an etic explanation. It is only by shifting to an etic, sociological perspective that 
In order to see the Durkheimian connection between the efficacy of religious discourse and the constitution of a social group in the case of the anatta doctrine, I find it helpful to understand the internalization of anattā in terms of Pierre Bourdieu's analysis of performative language. Against formalist analyses of performative speech like J. L. Austin's, Bourdieu argues that the source of the power of authoritative discourse does not lie in the intrinsic properties of the discourse but rather in "the institutional conditions of its production and reception." 111 In the final analysis, the authority of a given discourse is constituted by the collective recognition of the members of a social group. In applying this analysis of performative language to the anattā doctrine, one can begin by regarding the interiorized pronouncement, "this is not mine, this I am not, this is not myself," with respect to a given concept or experience as a performative. This pronouncement reverses and negates the acts of naming that establish the objects of conventional experience with their associated values. Now, what is the source of the authority thanks to which this formula can be used to disrupt and displace our everyday experience of self and world? On the most obvious level, the pronouncement is authoritative because it is taken to come from the Buddha himself and therefore to flow from his enlightenment experience. ${ }^{112}$ This claim that the formula comes from the mouth of the Buddha is in turn rooted in the authority of the Pāli Canon and the belief in the reliability of the tradition that has preserved it. ${ }^{113}$ From the perspective of a functionalist understanding of authority like that of Bourdieu or the theologian David Kelsey, the authority of the Anattalakkhana Sutta—its status as scripture, we might say—has to do with the way it and other canonical texts are used in the life of Buddhist communities. ${ }^{114}$ The recognition of its authority is instantiated in the practices of meditation, liturgical recitation, scholastic commentary, and doctrinal apologetics (among others). Ultimately, the effectiveness

the link between the psychological and political dimensions of anattā comes clearly into view. Buddhists themselves would appeal to the authority of the Buddha's enlightenment experience.

${ }^{111}$ Pierre Bourdieu, Language and Symbolic Power, trans. Gino Raymond and Matthew Adamson (Cambridge, MA: Harvard University Press, 1991), 111.

${ }^{112}$ And is conducive to enlightenment, as suggested by the conclusion of the Anattalakkhana Sutta in which the five original disciples attain liberation upon hearing the Buddha's discourse on anattā.

${ }^{113}$ Reynolds and Hallisey ("Buddhism," 337) argue that a central factor in the emergence of Buddhism as a new religious movement was the recognition of the Buddha and his enlightenment experience as "a new and ultimate source of sacred authority."

${ }^{114}$ David H. Kelsey (The Uses of Scripture in Recent Theology [Philadelphia: Fortress Press, 1975], 29-30, 109, 152) understands the authority of scripture (he is referring specifically to the Christian Bible) not to refer to a set of properties ascribed to the canonical texts but rather to the way these texts are used in the life of the community. 
of the anatta doctrine is rooted in the social reality of a community with a clear sense of Buddhist identity.

It is here, finally, with the identification of the social group as the basis of the authority of transformative discourse that the spiritual-transformative dimension of anattā links up with the oppositional-political. For as we have seen, the doctrine of anattā, by defining Buddhism over against other religious orders and movements, played-and continues to play ${ }^{115}$ - an important role in mobilizing and consolidating the identity of Buddhist communities. ${ }^{116}$ The refusal to name an experience as having a relation with a self represents, on the psychological level of self-analysis, the interiorized reflex of the "politically" motivated avoidance of the terminology-ätman and pudgala—of Buddhism's historical rivals.

In the foregoing argument, we have seen that the authority of anattā, manifest in its taboo character, represents the "missing link" between its soteriologically transformative and political-oppositional dimensions. And it is here that we see the significance of having categorized anatt $\bar{a}$ as a theological doctrine rather than as a philosophical proposition. For in doing so, we have considered the issue of authority, manifest both in its use in mobilizing communal identity and in bringing about psychological transformation, as integral to the discourse of anatta..$^{117}$

\section{CONCLUSION}

I have suggested the possibility that the use of the not-self doctrine to mark a contrast with Vedic Brahmanism was logically, if not also temporally, prior to its use as a conceptual resource in practices of personal transformation. If correct, anatta would thus be an example of a doc-

\footnotetext{
${ }^{115}$ An excellent (and well-known) example is Walpola Rahula, What the Buddha Taught (New York: Grove Press, 1974), 51, and cf. 52, 56. Rahula declares that "Buddhism stands unique in the history of human thought in denying the existence of such a soul, Self, or Ätman." He goes on to offer an invidious interpretation, à la Freud, of those religions affirming the existence of such an entity as catering to an infantile psychological need for self-protection (51-52).

${ }^{116}$ Here we note that the very opacity of the doctrine does not necessarily diminish, and indeed may actually enhance, its effectiveness in mobilizing communal identity. On this point, see, e.g., Southwold, "Buddhism and the Definition of Religion," 374: "This is why religions, as cultural systems in which empirically indeterminate doctrines are crucial, are so effective in identifying and distinguishing, unifying, and separating, cultural communities." The obscurity and ambiguity of the doctrine not only enhances its political effectiveness by rendering it amenable to a range of interpretations, but also preserves a structure of authority against the corrosive effects of rationalization.

${ }^{117}$ Stated differently, what is at stake in categorizing anatta $\bar{a}$ as doctrine is recognizing it as discourse, that is to say, as a linguistic form considered in relation to a particular context(s) of utterance.
} 
trine that begins its life as a marker of communal difference but which nevertheless becomes soteriologically transformative.

On the basis of analyses like the foregoing, one might hazard the generalization that oppositionally motivated doctrines like not-self or the divinity of Christ can have a transformative impact on the traditions whose identity they sustain. To the extent that such doctrines sustain a group's sense of identity, they are largely impervious to empirical discomfirmation and they resist modification. Indeed, under the right conditions, they show a tendency toward radicalization, as can perhaps be seen in the Sarvāstivāda and Theravāda responses to the Pudgalavāda ${ }^{118}$ or in the Christian doctrine of consubstantiality (a radical specification of the notion of Christ's divinity ${ }^{119}$ ), which was formulated in response to the Arian controversy. Existing forms of religious belief and practice-the concepts of karma and rebirth; the biblical doctrine of God-have to be looked at afresh and made to harmonize with these emergent formulations. Such doctrines can therefore take a tradition in directions that no one had originally anticipated. ${ }^{120}$

\footnotetext{
${ }^{118}$ I suspect that the Personalist Controversy played an important role in the development from the rather elusive expressions of anattā in the Nikāyas to the explicit formulations in later texts like the Abhidharmakośa and the Visuddhimagga.

${ }^{119}$ Originally, Christ's divinity was most likely understood in terms of the legitimate exercise of divine prerogatives, such as bestowing life or dispensing judgment (on this point, see Marianne Meye Thompson, The God of the Gospel of John [Grand Rapids, MI: Eerdmans, 2001], $47,52-54)$. The later understanding of Christ's divinity in terms of a shared essence or substance therefore represents a radicalization of this earlier understanding.

${ }^{120} \mathrm{I}$ am grateful to one of my anonymous reviewers for highlighting this aspect of my thesis.
} 
Copyright of Journal of Religion is the property of University of Chicago Press and its content may not be copied or emailed to multiple sites or posted to a listserv without the copyright holder's express written permission. However, users may print, download, or email articles for individual use. 